DOI:10.33099/2311-7249/2019-35-2-87-92

УДК 355.41

Володимир Олександрович Дачковський (кандидт технічних наук) Олександр Миколайович Сампір

Національний університет оборони Украӥни імені Івана Черняховського, Київ, Украӥна

\title{
АЛГОРИТМ ФУНКЦІОНУВАННЯ СИСТЕМИ ЛОГІСТИЧНОГО ЗАБЕЗПЕЧЕННЯ
}

\begin{abstract}
Досліджується проблема своєчасного забезпечення військових частин (підрозділів) необхідними матеріально-технічними засобами, боєприпасами, тощуо для виконання поставленого завдання. На основі аналізу виконання завдань підрозділами забезпечення в локальних війнах та збройних конфліктах та враховуючи досвід виконання завдань військовими частинами (підрозділами) на території Донецької та Луганської областей запропоновано алгоритм функиіонування перспективної системи логістичного забезпечення. Алгоритм спрямований на зменшення операційних витрат, забезпечення стабільної роботи системи логістичного забезпечення на усіх етапах - від закупівлі, зберігання та транспортування ракет, боєприпасів, матеріально-технічних засобів, тощзо до подачі їх у військові частини (підрозділи).
\end{abstract}

Ключові слова: логістичне забезпечення, відновлення, матеріально-технічні засоби, алгоритм функиіонування, інформаційні потоки.

\section{Вступ}

Реформування системи тилового і технічного забезпечення в систему логістичного забезпечення Збройних Сил (3С) України передбачає реалізацію системного підходу, який грунтується на поєднанні можливостей закупівлі, розподілу по рівнях військової ієрархії, транспортування, обслуговування і зберігання озброєння та військової техніки (ОВТ), матеріальних та матеріально-технічних засобів (МТ3), ракет i боєприпасів, тощо. Саме система логістичного забезпечення $є$ потужним інструментом забезпечення військ (сил), оскільки дозволяє оптимізувати рух невистачаючих зразків ОВТ, МТ3 боєприпасів, тощо у яких виникла потреба від баз, арсеналів, складів, військових частин забезпечення до військових частин, які виконують бойові завдання. А від якості зберігання та оперативності транспортування МТЗ залежить своєчасність забезпечення військових частин необхідними МТЗ, боєприпасами, тощо відповідно 3 найменшими фінансовими затратами. Логістичне забезпечення грунтується на принципах та методах, які дають змогу планувати, контролювати й управляти операціями, які виконуються в процесі закупівлі, постачання, технічного обслуговування (ТО), відновлення ОВТ, транспортуванні, тощо.

Постановка проблеми. Досвід застосування військ (сил) в локальних війнах і збройних конфліктах XX - XXI ст. свідчить, що несвоєчасне забезпечення військових частин, які виконують бойові завдання, МТЗ, боєприпасами, тощо, через неефективну систему забезпечення, призводило до зривів у виконанні поставлених завдань або взагалі до невиконання поставленого завдання. В цілому недостатньо розвинута, нескоординована, неусвідомлена та неефективна система забезпечення призводила до втрати військами (силами) територій, особового складу, ОВТ тощо.
Науково-технічний прогрес XXI ст. призвів до появи нових засобів ураження. Дані підстави спонукали до пошуку нових форм та способів ведення бойових дій, які вимагають підвищення рівня інтенсивності забезпечення військових частин (підрозділів).

Результати теоретико-методологічних i прикладних досліджень логістичного забезпечення активно впроваджуються в оперативну та стратегічну діяльність забезпечення військ (сил). Вдосконалення процесу своєчасного забезпечення військових частин необхідними МТЗ надасть можливість їх подачу з найменшими затратами та спрогнозувати потребу у МТЗ для закупівлі, що підтверджує актуальність даного дослідження.

Аналіз останніх досліджень і публікацій. Окремі питання теоретичного, практичного та методичного напрямку розглянуті у працях, як вітчизняних так і зарубіжних дослідників. Так у роботі [1] розглянуто поняття логістики, охарактеризовано іiї сутність, проаналізовано рівні логістичних систем, в роботі [2] визначено суть, принципи i функції військово-економічної логістики, а в роботах $[3,4]$ розглянуто основні принципи військової логістики, загальні питання організації логістики у військових частинах, наведено основні функції та завдання військової логістики. В [5] розглянуто проблеми реформування системи тилового забезпечення Збройних Сил України на основі сучасних підходів до управління в країнах НАТО, в [6] обгрунтовано ознаки та виокремлено етапи розвитку ринку логістичних послуг i охарактеризовані проблемні поля розвитку воєнної логістики, в роботі [7] запропоновано модель логістики раціонального переміщення машин та обладнання, яка грунтується на взаємодії засобів механізації та засобів для їх транспортування, у [8] досліджено критерії ефективності логістичного управління та запропоновано класифікацію 
логістичних інновацій, в роботі [9] розглянуто та доповнено властивості та принципи побудови логістичних систем, наведено класифікацію логістичних систем. Але, незважаючи на те, що значна кількість наукових досліджень уже проведена залишається невирішеним питанням щодо розроблення алгоритму функціонування системи логістичного забезпечення ЗС України, як в цілому так і за їі складовими.

Мета статті. Мета статті полягає у розробленні алгоритму функціонування підсистеми забезпечення матеріально-технічними засобами в інтересах підсистеми відновлення ОВТ, який буде покладений в основу алгоритму функціонування системи логістичного забезпечення в цілому.

\section{Виклад основного матеріалу}

\section{дослідження}

В сучасних умовах ведення бойових дій (операцій) перед керівництвом 3С України постають все більш складні завдання, пов'язані із забезпеченням військових частин (підрозділів) необхідними запасами ракет та боєприпасів, МТЗ, тощо, які необхідні для виконання поставленого завдання. Перш за все виникає потреба у досягненні стабільності на усіх етапах - від закупівлі, зберігання та транспортування ракет та боєприпасів, МТ3, тощо до подачі їх у військові частини (підрозділи).

Досвід виконання завдань військовими частинами (підрозділами) на території Донецької та Луганської областей вказує на те, що значно зростають вимоги до своєчасного забезпечення військових частин (підрозділів) необхідними боєприпасами, МТ3, тощо. Це формує об'єктивні передумови розвитку ефективної системи забезпечення, яка забезпечить швидку подачу МТ3 від баз, арсеналів, складів із різних рівнів ієрархії до військових частин (підрозділів), які виконують завдання за призначенням.

Виходячи 3 функцій системи логістичного забезпечення [10] для ЗС України найбільш притаманні наступні види логістичного забезпечення: закупівельна логістика, складська логістика, транспортна логістика, інформаційна логістика, логістика управління матеріальними та інформаційними потоками. Тому на скільки ці види логістичного забезпечення будуть між собою взаємодіяти, буде залежати ефективність усієї системи логістичного забезпечення ЗС України.

Крім того, необхідно враховувати, що у ЗС України система управління військами (силами) побудована на трьох рівня військової ієрархії. Відповідно система логістичного забезпечення також повинна функціонувати на трьох рівнях ієрархії і виконувати поставлені перед нею завдання. Виходячи 3 рівнів управління та видів логістичного забезпечення на стратегічний рівень будуть покладатись усі види логістичного забезпечення а на оперативний i тактичний усі крім закупівельної логістики. Тому логістичний підхід вимагає розглядати рівні ієрархії та функції логістичного забезпечення у сукупності на предмет інтегрованої оптимізації логістичної системи.
Прагнення до зменшення операційних витрат сприяло розвитку системи логістичного забезпечення, вдосконаленню зв'язків органів управління та військових частин, які виконують бойові завдання i тих, які їх забезпечують, на підставі оптимізації логістичних потоків. Завданням системи логістичного забезпечення $€$ організація та управління логістичними потоками, які поєднують військові частини,що виконують бойові завдання, військові частини забезпечення i органи управління на усіх рівнях ієрархії, а також внутрішні логістичні потоки, які забезпечують взаємодію усіх сфер діяльності та функціонування.

Логістичний підхід грунтується на ідеї наскрізного управління матеріальними потоками, сервісного обслуговування та функціонування складської логістики, що покладено в основу логістичної діяльності. Доцільність такого підходу демонструють ЗС країн НАТО, кожна з яких має свою систему логістичного забезпечення 3 відповідними структурами.

Логістичний підхід $\epsilon$ інтегральним інструментом менеджменту, який сприяє досягненню стратегічної, оперативної або тактичної організації забезпечення військових частин та зниження загальних затрат за рахунок ефективного управління матеріальними, інформаційними, фінансовими потоками, тощо.

Застосування логістичного підходу сприяє вирішенню одного з головних завдань - зниженню сукупних затратна забезпечення військових частин (підрозділів). Саме ефективне логістичне управління $є$ одним із важливих чинників реалізації потенціалу системи забезпечення ЗС України.

Дедалі відчутнішою стає необхідність у розвитку і впровадженні у практику логістичних інформаційних систем, які дозволили б органічно об'єднати в єдине ціле усі логістичні підсистеми. Це зумовлено тим, що інформація на сучасному рівні розвитку - це самостійний чинник, потенційні можливості якого відкривають широкі перспективи для зміцнення обороноздатності України[12]. При цьому інформаційна логістична система припускає створення автоматизованої системи, баз даних, комунікацій, комплексу заходів щодо прийняття управлінських рішень. Саме тому важливою складовою підвищення ефективності логістичної системи $є$ визначення та реалізація резервів економії або оптимізації витрат ресурсів. Слід зауважити, що підвищення ефективності діяльності передбачає врахування витрат, їх економію та оптимізацію на усіх етапах проходження матеріального, фінансового, інформаційного потоків тощо.

Розроблений алгоритм функціонування системи логістичного забезпечення повинен включати функції, вимоги до системи логістичного забезпечення та три рівня ієрархії системи управління військами (силами). Їх поєднання дозволить оцінити ефективність різних варіантів забезпечення військ (сил), відобразити у формалізованому вигляді процес логістичного забезпечення 3С України. Реалізація алгоритму може бути отримана за допомогою блоків, які 
передбачають часткові моделі. На рис. 1 представлено алгоритм функціонування системи логістичного забезпечення в інтересах підсистеми ТО і відновлення ОВТ, при цьому інші підсистеми системи логістики будуть функціонувати аналогічно підсистемі ТО і відновлення ОВТ.

Вихідними даними для реалізації алгоритму служать гранично допустимий час подачі МТ3 в інтересах підсистеми відновлення та зменшення фінансових витрат в інтересах усієї системи логістичного забезпечення.

Реалізація першого блоку покладається на штабну вертикаль управління логістичним забезпеченням. Яка у відповідності до [10] визначає потребу у МТ3, ракетах та боєприпасах, тощо у відповідності до визначених їй функцій.

Тобто, потреба військ (сил) і ремонтних органів в бронетанковому майні (БТМ) може визначатись або комплектами, або за окремими номенклатурами i буде формуватись на основі прогнозованих витрат на проведення відповідних видів ремонту, технічного обслуговування, тощо [11].

Розрахунок прогнозованої витрати БТМ i -i номенклатури визначається за формулою

$$
\mathrm{n}_{\text {ів }}=\mathrm{n}_{\text {іобсл }}+\mathrm{n}_{\text {i тех }}+\mathrm{n}_{\text {іб.п. }}+\mathrm{n}_{\text {іагр }}
$$

де $\mathrm{n}_{\text {iв }}-$ величина загальної витрати номенклатури БТМ за плановий період, од.;

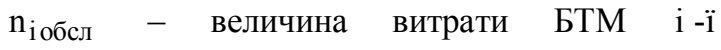
номенклатури на обслуговування БТОТ, од.;

$\mathrm{n}_{\mathrm{i} \text { тех }}-$ величина витрати БТМ i -ї номенклатури на ремонт БТОТ, що вийшли з ладу по технічним причинам, од .;

$\mathrm{n}_{\mathrm{iб.п.}} \quad-$ величина витрат БТМ i -ї номенклатури на ремонт БТОТ, що вийшли з ладу по бойовим пошкодженням, од .;

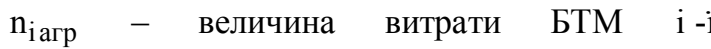
номенклатури на ремонт агрегатів БТОТ, од.

Витрата майна при проведенні технічного обслуговування визначається за формулою

$$
\mathrm{n}_{\text {іобсл0 }}=\sum_{\mathrm{k}=1}^{3} \mathrm{~N}_{\mathrm{k} \mathrm{обсл}} \mathrm{H}_{\mathrm{ik}}
$$

де $\mathrm{N}_{\mathrm{k} \text { обсл }}$ - кількість зразків БТОТ, яким в ході розглядаємого періоду буде проведено обслуговування k -го виду;

$\mathrm{H}_{\mathrm{ik}}$ - норма витрати $\mathrm{i}$-й номенклатури при k -му виді обслуговування.

Витрата майна при відновленні машин, які вийшли 3 ладу по технічним причинам, розраховується за формулою

$$
\mathrm{n}_{\text {i тех }}=\frac{\mathrm{D}_{\text {оп }}}{1000} \mathrm{~T}_{\mathrm{oi}}
$$

де $\mathrm{D}_{\text {оп }}$ - пробіг машин даної марки за бій (операцію), км;

$\mathrm{m}_{\text {оi }}$ - норма зміни i -ї деталі на машині, що має пробіг 1000 км.

Загальний пробіг БТТ кожної марки визначається виходячи з наявності БТТ на початок операції, виходу їх з ладу, глибини операції (протяжності маршруту під час проведення маршу) і коефіцієнта маневру машин в операції. Його величина визначається за формулою

$$
\mathrm{D}_{\text {оп }}=\sum_{\mathrm{j}=1}^{\mathrm{T}_{\Pi}} \mathrm{d}_{\mathrm{j}} \mathrm{k}_{\mathrm{M} \mathrm{j}} \mathrm{N}_{\mathrm{j}}
$$

де $\mathrm{T}_{\text {п }}$ - число днів планового періоду;

$\mathrm{d}_{\mathrm{j}}$ - передбачуваний пробіг БТТ в $\mathrm{j}$-й день операції, виміряний по карті, км;

$\mathrm{k}_{\mathrm{M} \mathrm{j}}$ - коефіцієнт маневру в $\mathrm{j}$-й день операції;

$\mathrm{N}_{\mathrm{j}}$ - кількість БТТ в строю в $\mathrm{j}-$ й день операції.

Кількість БТМ, необхідного для ремонту БТОТ, що вийшли 3 ладу від бойових пошкоджень, визначається за формулою

$$
\mathrm{n}_{\text {іб.п. }}=\mathrm{N}_{\text {пр }} \mathrm{V}_{\text {іп }}+\mathrm{N}_{\mathrm{cp}} \mathrm{V}_{\mathrm{icp}}+\mathrm{N}_{\text {кр }} \mathrm{V}_{\text {ікр }}
$$

де $\mathrm{N}_{\text {пр }}, \mathrm{N}_{\mathrm{cp}}, \mathrm{N}_{\text {кр }}$ - кількість поточних, середніх $\mathrm{i}$ капітальних ремонтів, запланованих до виконання за період;

$\mathrm{V}_{\text {iпр }}, \mathrm{V}_{\text {iсp }}, \mathrm{V}_{\text {iкр }} \quad-$ норми змінності $\mathrm{i}-і$ номенклатури при поточному, середньому i капітальному ремонтах БТТ.

Передбачувана витрата БТМ на капітальний ремонт агрегатів визначається за формулою

$$
\mathrm{n}_{\text {i агр }}=\mathrm{N}_{\text {јагр }} \mathrm{W}_{\mathrm{i}}
$$

де $\mathrm{N}_{\text {jагр }}$ - кількість капітальних ремонтів $\mathrm{j}$-х агрегатів, які заплановані до проведення в даній i нижчестоящій ланках за аналізований період;

$\mathrm{W}_{\mathrm{i}}$ - норми змінності i -ї деталі при капітальному ремонті $\mathrm{j}$-го агрегату.

Визначення потреби у інших МТЗ відповідно до визначених класів постачання буде здійснюватись аналогічно 3 використанням притаманних для даного класу моделей [13-14].

За допомогою програмно-технічного забезпечення щодо визначення потреби у ОВТ та МТ3 інформація вноситься до блоку електронної бази даних про встановлені норми зберігання ОВТ та МТ3 на складах військових частин, розподільчих центрах оперативного рівня, логістичних центрах стратегічного рівня.

Блок 2 передбачає внесення на стратегічному рівні до електронної бази даних встановлених норм напрацювання відповідними зразками ОВТ до ТО та ремонту згідно технічної документаціїдля усієї номенклатури зразків ОВТ та МТЗ та норми змінності і -ї деталі.

Блок 3 передбачає внесення на тактичному рівні інформації до електронної бази даних номерний облік ОВТ, агрегатів за усією номенклатурою.

Блок 4 надає можливість отримати інформацію про використання ресурсу відповідними зразками ОВТ, яка поступає у загальну електронну базу даних системи логістичного забезпечення в реальному масштабі часу. 


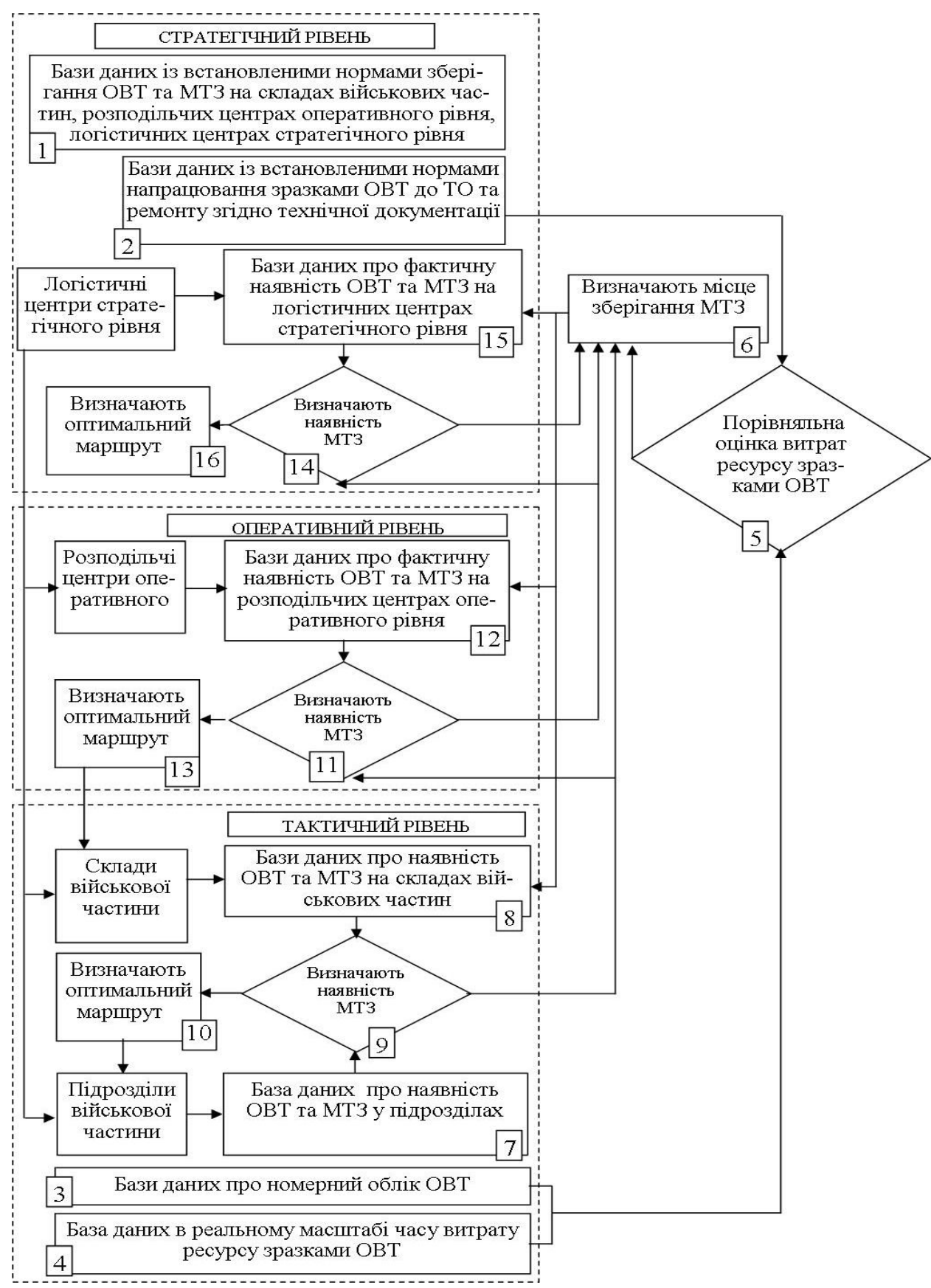

Рис. 1 Алгоритм функціонування системи логістичного забезпечення ЗС України

Блок 5 включає проведення порівняльної оцінки інформації, яка надійшла 3 блоку 4 в реальному масштабі часу щодо витрати ресурсу зразками ОВТ із інформацією блоку 2 встановлені нормами напрацювання зразками ОВТ до ТО та ремонту згідно технічної документації. Якщо витрата ресурсу зразками ОВТ, яку отримали в реальному масштабі часу наближається до встановленої норми напрацювання зразками ОВТ до ТО та ремонту тоді блок 6передбачає визначення місць зберігання МТ3, які необхідні для відповідного виду ТО або ремонту ОВТ. Визначення місця зберігання МТЗ передбачає моніторинг бази даних на тактичному, оперативному та стратегічному рівні, який здійснюе виконавча вертикаль системи логістичного забезпечення. При цьому, дана інформація також надходить до штабної вертикалі системи логістичного забезпечення, яка здійснює планування i закупівлю необхідних МТ3 для поповнення на складах зберігання.

Інформація, яка надходить 3 підрозділів військової частини формує базу даних про наявність ОВТ та МТЗ у підрозділах блоку 7, а інформація яка надходить із складів військової частини формує базу даних про наявність ОВТ та МТЗ на складах військової частини блоку 8.

Блок 9 передбачає визначення наявності МТ3 на тактичному рівні на основі даних блоку 7 та блоку 8. Якщо МТЗ, які необхідні для ТО або ремонту ОВТ $є$ у наявності в підрозділах військової частини сили і засоби підрозділів подають їх самостійно до відповідного зразка OBT, якщо відповідних МТ3 у підрозділі немає, але $\epsilon$ на складі військової частини у блоці 10 проводиться визначення оптимального маршруту 90 ISSN2311-7249(Print)/ISSN2410-7336(Onfine) Сучасні інббормахійні технолосіїу сббері безпеки та оборони № 2 (35)/2019 
їх підвезення. При цьому від безперебійної роботи транспортного забезпечення буде залежати своєчасність підвезення МТЗ відповідно і загальні витрати на підвезення. Крім того на своєчасність забезпечення будуть впливати можливості складської логістики 3 проведення вантажнорозвантажувальних робіт.

При цьому, якщо на тактичному рівні інформація надходить у блок 6 та блок 11. При цьому, інформація яка надходить 3 розподільчих центрів оперативного рівня формує базу даних про фактичну наявність ОВТ та МТЗ на оперативному рівні блок 12. Відповідно на оперативному рівні блоком 11 на основі бази даних блоку 12 визначається наявність МТ3 на оперативному рівні. Якщо МТЗ які необхідні для проведення ТО або ремонту $\epsilon$ у наявності визначається оптимальний маршрут їх підвезення на склади військової частини а за необхідності і у підрозділи. Якщо МТЗ які необхідні для проведення ТО або ремонту відсутні на оперативному рівні інформація надходить у блок 6 та блок 14.

Логістичні центри стратегічного рівня формують базу даних про фактичну наявність OBT та MT3 на логістичних центрах стратегічного рівня. Відповідно на стратегічному рівні блоком 14 на основі бази даних блоку 15 визначають наявність МТ3 на логістичних складах

\section{Лimepamypa}

1. Корнісцький О.В. Поняття та сутність логістики О.В. Корнієцький // Агросвіт. - 2015. - № 14. - С. 13-16. 2. Маслій О.М. Суть, принципи та функції військовоекономічної логістики / О.М. Маслій // Вісник Національної академії Державної прикордонної служби України - 2010. - Вип. 2. 3. Нестеренко О.М. Основні принципи та особливості організації логістики у військових частинах Національної гвардії України / Нестеренко О.М., Чирва Ю.Є. //YoungScientist - 2016. №5 (32). - С. 119-122. 4. Щербина В.В. Теоретичні аспекти реінжинірингу бізнес-процесів транспортнологістичних компаній / В.В. Щербина // Розвиток методів управління та господарювання на транспорті. 2015. Вип. 4 (53). - С. 19-35. 5. Нагорнічевський О. Державне управління реформуванням системи тилового забезпечення Збройних Сил України в контексті досвіду країн НАТО / О. Нагорнічевський // Державне управління та місцеве самоврядування. - 2015. - Вип. 2 (25). - С. 191-199. 6. Шандрівська О.С. Ідентифікація етапів розвитку логістичних послуг в Україні / O.С. Шандрівська, О.С. Костюк, Т.В. Наконечна // Вісник Національного університету “Львівська політехніка". Логістика. - 2015. - № 833. - С. 118- 124. 7. Шатов С.В. Логістика переміщення засобів механізації під час розбирання руйнувань будівельних об'єктів / С.В. Шатов, М.Ю. Улітіна // Вісник Придніпровської державної академії будівництва та архітектури. - 2016. №12 (225). - С. 20-25. 8. Гришко В.В. Інноваційний характер управління якістю в логістичних системах / B.B. Гришко, В.В. Ржепішевська // Вісник Чернівецького торговельно-економічного інституту. Економічні науки. - 2016. - Вип. 1. С. 103-112. стратегічного рівня. Якщо МТЗ які необхідні для проведення ТО або ремонту $\epsilon$ на логістичних складах стратегічного рівня визначається найближчий склад та визначається оптимальний маршрут їх підвезення на розподільчі центри оперативного рівня, а за необхідності на склади військової частини. Якщо МТЗ відсутні на логістичних складах стратегічного рівня вживаються негайні заходи щодо їх закупівлі.

\section{Висновки й перспективи подальших досліджень}

Узагальнюючи вищевикладене, слід зазначити, що логістичні системи військового призначення повинні бути адаптивними та своєчасно реагувати на виклики, які виникають.

Формування системи логістичного забезпечення в ЗС $є$ вимогою часу i сприяє вирішенню важливого питання, яке полягає у скороченні витрат на забезпечення військ. Саме тому активізація логістичної функції спонукає до реалізації можливостей не лише закупівлі, а i зберігання та транспортування ОВТ та МТЗ.

Логістична система може ефективно функціонувати за умови отримання необхідного обсягу інформації. Для розвитку логістичних систем потребує постійного вдосконалення система інформаційних потоків.

9. Метеленко Н.Г. Логістична система підприємства машинобудівної галуззі у логістичному менеджменті / Н.Г. Метеленко, К.С. Тарабан // Финансы, учет, банки. 2014. -Вып. 1. С. 196-202. 10. Основні положення логістичного забезпечення Збройних сил України [Електрон. ресурс]: наказ МОУ від 11 жовтня 2016 № 522. - Режим доступу: http://www.mil.gov.ua/ ministry/normativnopravova-baza/nakazi-ministra

oboroniukraini/nakazi-ministerstva-oboroni-ukrainiza-2016rik.html. 11. Дачковський В.О., Оперативні розрахунки завдань технічного забезпечення (методика та приклади) / В.О. Дачковський, І.В. Овчаренко, О.В. Ярошенко, Н.К. Багдасарян - К: НУОУ ім. Івана Черняховського, 2018. 116 с. 12. Вишневська О.М. Особливості логістичних систем сільськогосподарських підприємств / О.М. Вишневська, Т.В. Двойнісюк, С.В. Шигида // Глобальні та національні проблеми економіки. -2015 . - Вип. 7. С. 106-109. 13. Голобородько М.Ю. Формалізована модель матеріального забезпечення військ (сил) / М.Ю. Голобородько, В.І. Білєтов, В.І. Галаган, К.В. Панадій, C.В. Бондарчук // Збірник наукових праць Центру воєнно-стратегічних досліджень Національного університету оборони України імені Івана Черняховського. - 2014. - № 1 (50). - С. 48-53. 14. Рибидайло А.А. Аналіз шляхів поліпшення складської логістики воєнного відомства / А.А. Рибидайло, В.О. Бойко, О.С. Левшенко, І.Г. Зотова, В.В. Грицюк// Збірник наукових праць Центру воєнностратегічних досліджень Національного університету оборони України імені Івана Черняховського. - 2016. № 1. - С. 63-68.

\section{АЛГОРИТМ ФУНКЦИОНИРОВАНИЯ СИСТЕМЫ ЛОГИСТИЧЕСКОГО ОБЕСПЕЧЕНИЕ}

\section{Владимир Александрович Дачковский (кандидат технических наук) Александр Николаевич Сампир}

Национальный университет обороны Украины имени Ивана Черняховского, Киев, Украина 
Исследуется проблема своевременного обеспечения военных частей (подразделений) необходимыми материально-техническими средствами, боеприпасами $и$ т.д. для выполнения поставленной задачи. На основе анализа выполнения задач подразделениями обеспечения в локальных войнах и вооружённых конфликтах и учитывая опыт выполнения задач военными частями (подразделениями) на территории Донецкой и Луганской областей предложен алгоритм функиионирования перспективной системь логистического обеспечения. Алгоритм направлен на уменьшение операционных расходов, обеспечение стабильной работы системы логистического обеспечения на всех этапах - от закупки, хранения и транспортировки ракет, боеприпасов, материально-технических средств и т.д. до подачи их в воинские части (подразделения).

Ключевые слова: логистическое обеспечение, восстановление, материально-технические средства, алгоритм функционирования, информационные потоки.

\title{
ALGORITHM OF LOGISTIC PROTECTION SYSTEM OPERATION
}

\author{
Volodymyr Dachkovskyi (Candidate of Technical Sciences) \\ Oleksandr Sampir
}

\section{National Defence University of Ukraine named after Ivan Cherniakhovsky, Kyiv, Ukraine}

The problem of timely provision of military units (units) with the necessary material and technical means, ammunition, and others for the accomplishment of the task is investigated. Based on the analysis of the implementation of tasks by units of support in local wars and armed conflicts and taking into account the experience of performing tasks by military units (units) on the territory of Donetsk and Luhansk regions, an algorithm for the functioning of a promising logistics system is proposed. The algorithm is aimed at reducing operating costs, ensuring the stable operation of the logistics system at all stages, from the procurement, storage and transportation of missiles, ammunition, logistical equipment, and more to serve them in military units (subunits).

Keywords: logistics, restoration, material and technical means, algorithm of functioning, information flows

\section{References}

1. Kornietsky O.V. The concept and essence of logistics / O.V. Kornicky // Agrosvit. - 2015. - No. 14. - P. 13-16. 2. Masliy O.M. The essence, principles and functions of military-economic logistics / O.M. Masliev // Bulletin of the National Academy of the State Border Guard Service of Ukraine - 2010. - Vip. 2. 3. Nesterenko O.M. Basic principles and peculiarities of organization of logistics in military units of the National Guard of Ukraine / Nesterenko O.M., Chirva Yu.E. // YoungScientist - 2016 - No. 5 (32). P. 119-122. 4. Shcherbyna V.V. Theoretical aspects of reengineering business processes of transport and logistics companies / VV Shcherbyna // Development of methods of management and management in transport. - 2015 y. 4 (53). - P. 19-35. 5. Nagornichevsky O. The State Department for Reforming the Logistics System of the Armed Forces of Ukraine in the Context of NATO / O. Nagornichevsky // State Administration and Local Self-Government. - 2015. Issue 2 (25). - P. 191-199. 6. Shandrovskaya O.E. Identification of the stages of development of logistics services in Ukraine / O.E. Shandrovskaya, O.S. Kostyuk, T.V. The final // Bulletin of the National University "Lviv Polytechnic". Logistics - 2015. - № 833. - P. 118-124. 7. Shatov SV Logistics of moving mechanization facilities during dismantling of destruction of construction objects / S.V. Shatov, M.Yu. Ulytina // Bulletin of the Pridneprovsk State Academy of Civil Engineering and Architecture. 2016 - No. 12 (225). - P. 20-25. 8. Grishko V.V. Innovative character of quality management in logistics systems / VV Grishko, V.V. Rzhepyshevskaya // Bulletin of the Chernivtsi Trade and Economic Institute. Economic Sciences. - 2016. Voip. 1. P. 103-112. 9. Metelenko N.G. Logistics system of the machine-building industry in logistics management / N.G. Metelenko, K.S. Drum / / Finance, accounting, banks. 2014. -Weap. 1. P. 196-202. 10. The main provisions of the logistic support of the Armed Forces of Ukraine [Electron. resource]: Order of the Ministry of Education and Science of October 11, 2016, No. 522. - Mode of access: http://www.mil.gov.ua/ ministry / normativnopravova-baza / nakazi-minister oboroniukraini / nakazi-ministerstvaoboroni-ukrainiza-2016-rik .html 11. Dachkovskyi V.O, Operative calculations of technical maintenance tasks (methodology and examples) / V.O. Dachkovsky, IV Ovcharenko, O.V. Yaroshenko, NK Baghdasaryan - K .: NUOU them. Ivan Chernyakhovsky, 2018. - 116 p. 12. Vishnevskaya O.M. Features of logistic systems of agricultural enterprises / O.M. Vishnevskaya, T.V. Dvanniyuk, SV Shigida // Global and national problems of the economy. - 2015. - Issue 7. P. 106-109. 13. Goloborodko M.Yu. Formalized model of material support of troops (forces) / M.Yu. Goloborodko, VI Biletov, VI Galagan, K.V. Panadiy, SV Bondarchuk // Collection of scientific works of the Center for military-strategic research of the National University of Defense named after Ivan Chernyakhovsky. - 2014 - No. 1 (50). - P. 48-53. 14. Ribidailo A.A Analysis of ways to improve the warehouse logistics of the military department / AA Ribidailo, VO Boyko, O.S. Levchenko, IG Zotov, VV Gritsuk // Collection of scientific works of the Center for military-strategic research of the National University of Defense named after Ivan Chernyakhovsky. - 2016. - No. 1. - P. 63-68. 